\title{
Between Polycentrism and Bipolarity
}

\section{On Russia’s World Order Evolution Narratives}

Andrey V. Kortunov

\section{Abstract}

The concept of multipolarity, at least in Russia, remains an eclectic assortment of general political statements and observations concerning important, but separate, global development trends. Multipolarity, as an inevitable and desired state of the international system (a new world order), has been put on hold until an increasingly distant future and is clearly evolving (especially in official political narratives) towards the old Soviet-era bipolar outlook on world politics. This evolution, different aspects of which are analyzed in this article, creates substantial potential challenges to Russia's positioning in the emerging system of international relations and slows down the development of the Russian theory of international relations. A convincing alternative to the multipolar concept is a multilateral one. The differences between the two are identified and analyzed in the final section of this article.

Keywords: polycentric world, multipolar world, multilateral world, Russian official political narratives, new bipolarity, IR theory

\author{
Andrey V. Kortunov \\ Russian International Affairs Council (RIAC), Moscow, Russia \\ Director General \\ ORCID 0000-0002-3897-6434 \\ Scopus AuthorID 24782993000 \\ E-mail: akortunov@russiancouncil.ru \\ Tel.: +7 (495) 2256283 \\ Address: 1 Bolshaya Yakimanka Str., Moscow 119180, Russia
}

DOI: $10.31278 / 1810-6374-2019-17-1-10-51$ 
Throughout most of post-Soviet history, the prevalent world order evolution narrative in Russia was the one that envisioned

a gradual transition from bipolarity (Cold War period) to a "unipolar moment" (mid-1990s) and further towards a multipolar, or polycentric, world. As a rule, no one tries to look beyond the distant horizons of "mature polycentrism" in Russia. Although the substance of this multipolarity, the specific trajectory of systemic shifts and their significance for international stability have been actively discussed in the Russian expert and political communities, the very fact of the international system's evolution towards multipolarity can be considered generally recognized. The terms 'multipolar' and 'polycentric' are most often used interchangeably in Russia's official and expert rhetoric, and the former can be found more often than the latter. There are nuances in meaning, but both terms put emphasis on the "power hubs" of the modern world (poles and centers) rather than communication between them (as in "multilateralism").

The desirability and historical predetermination of multipolarity are most often associated with Yevgeny Primakov. In fact, the former foreign minister announced the start of transition towards a multipolar world in 1996 as one of the main trends in the development of international relations (Primakov, 1996). In April 1997, with Primakov's active participation, the leaders of Russia and China signed the Joint Declaration on a Multipolar World and the Establishment of a New International Order (Declaration, 1997). While Russia's Foreign Policy Concept of 1993 noted the "disappearance of the bipolar structure on a global scale" and "multivariance of world politics due to the disappearance of the bipolar structure" (Shakleina, Torkunov, et al., 2002, p. 22), Russia's National Security Concept of 1998 stated that "the current international situation is characterized by growing tendencies towards forming a multipolar world" (Ibid., p. 51). During his visit to New Delhi at the end of 1998 as prime minister, Primakov proposed creating a mechanism of trilateral cooperation between Russia, China, and India (RIC) as a practical step towards institutionalization of global multipolarity. Primakov's outstanding role in the development of the multipolar world concept 
was subsequently stressed by Sergei Lavrov (2014), who repeatedly mentioned it in his speeches and articles.

It will be fair to say that the concept of multipolarity has been part of Russia's foreign policy discourse at least since the early 1990s (see, for example, Rogov, 1992). Primakov's predecessor as foreign minister, Andrei Kozyrev, actively used the term 'multipolar world' in his speeches $(1994$, p. 9): “...It is quite obvious already now that the world in the 21 st century will be neither Pax Americana nor any new version of the bipolar system. It will be multipolar." In the first half of the 1990s, the idea of multipolarity was to a large extent not so much practical (as in the case of Primakov) as political and psychological, designed to help present Moscow's declining status in the international system as a manifestation of more general global political trends.

International relations experts in the West are least likely to agree with the priority of the Russian politician and scholar. As a rule, they date the concept of multipolarity to the mid-1970s and look for its roots in the rapid economic rise of Western Europe and Japan, America's defeat in Vietnam, the energy crisis of 1973-1974, and other global political trends that do not fit into the rigid framework of the bipolar world. The creation in 1973 of the Trilateral Commission, which was tasked with finding a new format for relations between North America, Western Europe, and East Asia, reflected imminent, if not already achieved, multipolarity, at least in the Western world. On the other hand, Henri Kissinger's successful efforts to play on SovietChinese contradictions in the early 1970s signified the recognition of multipolarity in the once monolithic communist bloc.

Interestingly, at the turn of the century, the idea of multipolarity became so popular in the United States that then National Security Adviser Condoleezza Rice thought it necessary to publish an article severely criticizing multipolarity as a concept of rivalry and potential conflicts that distracted humankind from tackling common creative tasks. According to Rice, the future of international relations should be based on the unity of values, not on the balance of power. Naturally, this rhetoric was designed to assert the "unipolar moment" as the best model of world politics for as long as possible, preferably forever (Rice, 2003). 
Chinese historians, for their part, have a right to speak about their own version of multipolarity-duojihua-developed in the early 1990s and rooted in Mao Zedong's theoretical legacy. China formulated an original view on the peculiarities of transition from a unipolar world to a multipolar one through a "hybrid" structure of world politics which combines elements of both old and future world orders. China's seventh Foreign Minister Qian Qichen stated: “The world is still in transition, and a new model is not fully formed yet, but the contours of the structure of international relations can already be seen. In it, one superpower and several great powers exist in a state of interdependence and struggle... this is the initial period in the system's evolution towards multipolarity" (Zhao, 2004, p. 142).

Regardless of how we date the concept of multipolarity and who we consider its author, it is obvious that this concept was not invented recently but is an intellectual product of last century. It would seem that over the past decades multipolarity should have evolved from a concept into a full-fledged theory. As for political practice, intuition suggests that a multipolar world should have become fully formed over these decades as a new system of world politics, with its own norms, institutions, and procedures. In fact, in his article "The Present and the Future of Global Politics” (2007), published a decade after Primakov's essay in Mezhdunarodnaya Zhizn (International Affairs), Foreign Minister Sergei Lavrov spoke about multipolarity as an accomplished fact: "The experience of the last six years (apparently referring to a period from 2000 to $2006-A K$ ) convincingly shows that any attempts to ignore the reality of a multipolar world ultimately end in failure."

However, neither has happened so far. The concept of multipolarity, at least in the Russian official discourse, remains an eclectic assortment of general political statements and observations concerning important, but separate, global development trends. This concept is used depending on the situation, highlighting different manifestations of growing geopolitical and geo-economic pluralism at different times. However, multipolarity, as an inevitable and desirable state of the international system (a new world order), has been put on hold until an increasingly distant future. Moreover, there are grounds to say that 
amid deteriorating relations with the West over the past several years the concept of multipolarity has been clearly evolving towards the old Soviet-era bipolar outlook on world politics, adjusted for the new realities of the second decade of the 21 st century.

This evolution, different aspects of which are analyzed in this article, creates substantial potential challenges to Russia's positioning in the emerging system of international relations and slows down the development of the Russian theory of international relations. In this work I attempt to identify the most obvious methodological problems concerning multipolarity, expose its inner contradictions, compare the multipolar and bipolar views of the world, and draw attention to an alternative concept for describing the future world order-the concept of multilaterality (the author's views are summarized in: Kortunov, 2016; Kortunov, 2018a).

The main conclusions made after analyzing Russian narratives concerning the evolution of the world order over the past two decades are as follows:

- Over the past twenty years the concept of multipolarity has failed to acquire most of the functions needed for becoming a full-fledged scientific theory (organizing and summarizing knowledge, focusing, elucidating, observing, heuristic, communicative, normative, and generative functions-see Littlejohn, 1994, pp. 28-29);

- The system of indicators which could reliably measure progress (regress) in the transition of the international system towards multipolarity remains unclear; likewise, there are no reliable forecasts as to when the transition from the unipolar world towards a multipolar one may be completed;

- The concept of "hybrid" systems combing elements of unipolar and multipolar concepts ("pluralistic unipolarity" and "asymmetric multipolarity") has not become a subject of sequential critical analysis and theoretical investigation;

- The historical experience of previous multipolar systems (primarily the system of relations between great European powers in 1814-1913) cannot be used as the basis for modern 
theories of multipolarity due to deep differences in the socioeconomic and political-ideological contexts);

- The driving forces and mechanisms of possible consolidation of the emerging "poles" within a multipolar system as well as the mutual attraction between the "core" and the periphery of a "pole" in many cases turns out to be a sheer hypothesis which is not proved empirically;

- Russia's foreign policy discourse of the last several years is slowly returning from the previously generally accepted multipolarity towards the old Soviet-era bipolar narratives which are undergoing various methodological transformations;

- Attempts to combine bipolar approaches with multipolar ones in order to describe international relations are unproductive due to fundamentally different and methodologically incompatible principles of the two approaches;

- A multilateral concept could become a promising area for the development of the Russian theory of international relations; despite some phonetic similarity, it nevertheless differs substantially from the concept of multipolarity;

Most of the material used in this article was found in official Russian narratives-speeches and articles by Russian leaders and official documents concerning Russia's foreign policy. Quotes from and references to Russian studies pertaining to the theory of international relations, which are cited in this work, do not claim to be complete and are used mainly for illustrative purposes.

I also admit that many of the thoughts stated herein are schematic and disputable and need further elaboration and, therefore, I suggest considering this work as an invitation to active expert discussion on the modality of the future world order and a desired (and practically achievable) place of Russia in this world order.

\section{A CONCEPT THAT HAS NEVER BECOME A THEORY}

Precisely twenty years after the publication of Yevgeny Primakov's major policy article in International Affairs, President Vladimir Putin, 
addressing an annual Valdai Club meeting in Sochi in October 2016 (2016b), said: "I would hope very much [...] that the world will become truly multipolar so that the opinions of all members of the international community are taken into account." Six months prior, speaking about the role of the United States in international relations, he stressed: "America is a great power. Today it is perhaps the only superpower. We acknowledge that" (Putin, 2016a). In other words, although a multipolar world is a desirable model of the world order for the Russian leadership, it would be premature to say now that the "unipolar moment" has been overcome completely.

Foreign Minister Sergei Lavrov (2017), following Yevgeny Primakov's overall logic and even style of twenty years ago, also spoke about the start of transition towards multipolarity but expected it to continue indefinitely long. "... a change of eras always takes a very long time, and it will continue for a long while." As a major complication he named the stubborn resistance by the advocates of the old world order. "There have been active attempts to hamper this process, primarily by those who used to dominate the world and who want to preserve their domination in the new conditions, essentially, forever" (Ibid). In one of his latest speeches, the Russian minister stressed again that the transition to a multipolar world would take "several decades" and its final outcome could not be considered predetermined (Lavrov, 2019).

The transition from bipolarity to polycentrism through unipolarity as a long process rather than an accomplished fact has been stated in many official documents related to Russian foreign policy and national security. For example, Russia's Foreign Policy Concept (Concept, 2016) states: "The modern world is going through a period of major transformations, the essence of which boils down to the formation of a polycentric international system. The structure of international relations becomes increasingly complex. The process of globalization produces new centers of economic and political influence. The global potential of power and development becomes dispersed ..." According to the wide-spread Russian narrative, a new world order is slowly "growing through" the decaying fabric of old unipolarity; new tendencies, regimes, and institutions are developing slowly and 
unevenly across the world, which in the long run should lead to global qualitative changes. But the general movement towards multipolarity does not rule out periods of "temporary stabilization" of the old, predominantly unipolar, system.

This narrative, though logical and consistent, leaves a number of questions open, firstly, those concerning a long transition from one system to another. The historical experience of the last several centuries offers no examples of a gradual, long and relatively painless transition from the old world order to a new one. In 1555 (the Peace of Augsburg), in 1648 (Westphalian system), in 1815 (Concert of Europe), in 1919 (the Treaty of Versailles), and in 1945 (Yalta-Potsdam system), the world order was changed not by evolutionary but solely revolutionary (forcible) methods and its change was preceded by large-scale armed conflicts. New world orders, as a rule, were built by the victors in their own interests.

Naturally, one can assume that the past experience may not necessarily be applicable in the 21 st century. But the very algorithm of possible transformation of "quantity into quality," that is, the mechanism through which a host of separate, situational and incremental changes can produce a global system shift has no historical precedents and remains unclear. The ideas of Russian political scientist A. Fenenko (2018) about what could catalyze the transition from "a unipolar moment" towards a multipolar world deserve special mention: "How could a collapse of the unipolar world look like? The most probable scenario would be the United States' defeat in a major regional war. Sinking American aircraft carriers and destroyers, downed American aircraft, American cruise missiles seized by the victor, hundreds of killed American soldiers and the U.S. president helplessly running about would be the most graphic picture of the end of unipolarity. Another scenario would be a severe political crisis in the United States similar to that in the Soviet Union in 1989-1991, which would lead to a secession of some of its states and withdrawal of American troops from allied territories. A third scenario describes a deep economic crisis in the U.S. comparable with the Great Depression of 1929-1933, which would result in a collapse of economic globalization and bring 
nationally-oriented economies back into play. Anyway, it should be an event that would weaken the United States dramatically and change the balance of power in the world."

As we can see, "the transformation of quantity into quality" presupposes a major cataclysm. In other words, a smooth and relatively painless transition to a new world order cannot be observed. It must also be noted that A. Fenenko's scenarios of the end of the "unipolar moment" contain tremendous and barely calculable risks not only for the United States itself, but also for all the other international players.

Secondly, if we accept as a given that the transition to a multipolar world will become a historically long process taking, say, five decades (for example, from 1995 to 2045; in his last works (2011) Primakov expected multipolarity to become generally established by the end of the second or the beginning of the third decade of the 21st century), then we will come to a sad conclusion that mankind is doomed to be trapped in the "gray zone" between the old and a new world orders until the middle of the current century. This "gray zone" is not a very comfortable or safe place, predictably with no rules of the game, or clear and generally recognized principles of functioning of the international system, and is plagued with numerous conflicts between emerging "poles." We leave out the question of whether even "mature" multipolarity can ensure international stability and security and to what extent. This is a matter of active discussions and its positive outcome is not so obvious to everyone.

However, it is not conflicts as such that matter but the mechanisms that can be used to resolve them. Vladimir Lenin once famously said: "Before we can unite, and in order that we may unite, we must first of all draw firm and definite lines of demarcation." For the world to reunite on a new basis in the future, mankind will obviously have to go through a period where the old system will disintegrate into separate fragments and its "poles" will become self-secluded within their respective regional or continental subsystems for the sake of inner consolidation of each of the "poles."

In fact, we are already witnessing this disintegration and signs of looming self-seclusion. Let us assume that it will go relatively 
smoothly and without conflicts, which in itself is a big assumption. Drawing a somewhat risky historical analogy, let us compare the current approach in world politics with the transition from the era of early feudal European states (the empire of Charles the Great, Kievan Rus) to the period of feudal disunity. It is not quite clear when and in what format the process similar to the restoration of centralization in the era of late feudalism will take place, or on what basis the lost integrity of the international system will be restored and what may catalyze such restoration.

In other words, what can make system-wide interests prevail over national particularism? A large military conflict? A global shortage of resources? A new Great Depression? Dramatic climate changes? A large-scale terrorist act involving nuclear weapons? Or artificial intelligence that has slipped out of control? At any rate, the current Russian discourse offers no convincing answer to this question.

Thirdly, are there really any objective reasons to say that the world is moving, albeit slowly by fits and starts, towards multipolarity? Do we have any reliable indicators to measure the speed and steadiness of this movement (general data (economic growth rates in individual countries, demographic changes in the world, military spending dynamics, etc.) can hardly serve as credible pointers suggesting that the international system is gravitating towards multipolarity)? Can one reliably say, for example, that the European Union today is closer towards becoming a full-fledged and independent global "pole" than it was ten years ago? Or that Africa, the Middle East or Latin America has come closer to the status of such collective "pole" over the past ten years? Or that the enlargement of the SCO has made it more capable of acting concertedly on the international stage?

Ten years ago Primakov wrote (2009, p. 12): "Undoubtedly, the number of poles will not remain the same as now. New ones will emerge. For example, rapid economic growth is more and more often registered in Brazil and South Africa. Integration processes will develop in Latin America, Asia, Africa, and the Middle East, forming new 'group' centers of world economy and politics." The past decades did not prove him right. On the contrary, in the second decade of the 
21st century "intra-regional" competition increased in a considerable part of the global "periphery," among other things, for better terms of connection to the world "core."

Even India, which has traditionally been regarded as one of the most promising poles in its own right in the forthcoming era of multipolarity, has been consistently building closer cooperation with the United States in the past ten years. In fact, if China's rapid rise and the obvious deterioration of its relations with America in recent years are removed from the present picture of the world, little will be left of the declared "global" drift towards multipolarity. But Sino-American confrontation, even if it escalates, may not necessarily lead to the emergence of a "mature" multipolar world and may in fact lead the world to a completely different system of international relations.

If there are no clearly affirmative and empirically verifiable answers to the questions pertaining to the dynamics of foreign policy aspirations of the majority of regions in the world, we probably cannot say that the world is steadily moving towards multipolarity. "No one has seriously challenged the liberal world order or the U.S. as the only superpower," Vyacheslav Sutyrin says (2016, p. 30). "But each tries to protect his positions in the regions of strategic interests in his own way. Would this be enough to declare a collapse of the old world order? Obviously not."

The Russian discourse reveals multidirectional political, and financial and economic trends. While the former indicate a movement towards multipolarity, the latter, on the contrary, suggest that the "unipolar moment" remains strong (see Timofeev, 2019, for example). The picture becomes even less clear and more confusing if one tries to take into account technological, scientific, educational, sociocultural and other aspects of modern international relations. Multipolarity, therefore, is no more than an image of the desired world order, drawn in the thinnest dashed lines.

\section{THE FALSITY OF HISTORICAL PARALLELS}

The advocates of multipolarity prefer to cite the historical experience of the Concert of Europe, or the Vienna system of international relations, 
created in the early 19th century after the Napoleonic wars (Nikonov, 2002). This construct was in fact largely multipolar (although the history of the 19th century in most cases is interpreted as a history of bipolar confrontation between the Russian and British Empires) and helped preserve peace in Europe for a long period of time. Historians argue about when exactly that system was torn down-in 1853 (Crimean War), in 1871 (Franco-Prussian War) or in 1914 (World War One). At any rate, the 19 th century after 1815 was relatively peaceful for Europeans, especially compared to the catastrophic 20th century that followed it.

But is it possible in principle to repeat the experience of the Concert of Europe two centuries on, not on a European but on a global scale this time? Or at least use its model for describing the desirable system of international relations in the 21st century?

To begin with, members of the Concert of Europe, while being different state entities, were comparable in terms of power and influence-military, political, and economic. The cosmopolitan European elites were mostly homogenous (European monarchies in the 19th century essentially were one family), spoke the same language (French), professed the same faith (Christianity), and by and large shared the same cultural tradition (European Enlightenment). What is even more important is that there were no fundamental or irreconcilable disagreements between members of the Concert of Europe over the anticipated future of European politics, at least until Prussia's rapid rise and the subsequent unification of Germany.

The current situation is completely different. Potential members of the multipolar system differ profoundly in terms of weight. By most parameters, the United States has a greater weight in the modern international system than the British Empire did in European politics in the 19th century. The U.S. GDP is not the only reason. It is much more important that the U.S. occupies a central place in the world currency and financial system, major international technological chains, global scientific and educational networks, etc. Over the past several years it has also asserted its central role in 
the world energy sector, where the "shale" revolution has enabled it to become the main regulator of international hydrocarbon prices.

Russian international relations experts have struggled vigorously to solve the problem of weight difference in the multipolar balance of the 21st century. Their efforts produced numerous "hybrid" concepts, which are somehow consonant with similar Chinese constructs, ranging from "pluralistic unipolarity" (Bogaturov, 1996) to "asymmetric multipolarity" (Torkunov, 1999). However, the rules of the game in the system where its participants had different weight remained unclear, and the system itself in most cases was regarded as transitional and gradually evolving towards "mature" (and therefore, more stable) multipolarity.

The situation is complicated by the fact that the world elites are extremely heterogeneous as borne out by glaring differences in the cultural architypes and basic values they adhere to. In the 19th century, disagreements between members of the Concert of Europe centered mainly around concrete aspects of European politics and ways to manually tune up the complex European mechanism. In the 21st century, disagreements between great powers focus on thefundamentals of the world order, basic principles of international law and even more intensely on the general notions of justice and legitimacy, and "great meanings" in history. Responding to the advocates of the 19th century system of international relations, Vladimir Putin (2006), at a meeting with Russian ambassadors and permanent representatives on June 27, 2006, said: “...We are not going to participate in any 'holy alliances." This statement most likely reflected the Russian leader's awareness of the fact that there were only a few points of contact between Russia and its Western partners.

Socio-cultural homogeneity of the European ruling aristocracy, as Russian researcher V. Batyuk has rightfully pointed out, produced "an unprecedentedly high level of mutual trust between Europe's ruling elites of that time" (Batyuk, 2010, p. 85). Speaking of the contemporary international system, he observes further: "The absence of the aforementioned socio-cultural homogeneity has been made up for by the growing role of international law and international organizations 
in the modern world" (Ibid). While the former statement can hardly be contested, the latter observation regarding the "compensatory" role of international law appears to be quite arguable: latest events have clearly exposed the increasing fragility of international law and relevant institutions amid the dramatically dwindling trust between major global players.

On the other hand, the successful functioning of the Concert of Europe was largely due to its flexibility. Great European powers could afford the luxury of changing the configuration of their alliances and coalitions quite promptly in order to keep the system in equilibrium. For example, France was one of Russia's main adversaries during the Crimean War, but a year after the signing of the Treaty of Paris in 1856 the two countries became quite active in building a closer relationship, which resulted in Russia's final breakup with Austria and the latter's defeat in the conflict with France in 1859.

Can such flexibility be possible nowadays? Can we assume that Russia is able to move from its current partnership with China to an alliance with the U.S. within two or three years? Or that the European Union, faced with growing pressure from the U.S., will opt for strategic cooperation with Moscow? Such assumptions, at the very least, are implausible or even utterly absurd. Alas, the present leaders of great powers lack the flexibility that is absolutely necessary for maintaining a stable multipolar world order.

Winding up a brief historical journey, let us ask one more interesting question. Why did the Congress of Vienna in 1814-1815 produce a stable European order but the Treaty of Versailles in 1919 lost its relevance just fifteen years after its signing? Why could the participants in the anti-French coalition show their magnanimity and greatheartedness with regard to their former adversary, but members of the anti-German coalition did not? Was it because Georges Clemenceau, David Lloyd George and Woodrow Wilson were duller or more bloodthirsty than Alexander I, Klemens von Metternich and Charles Maurice de Talleyrand?

Certainly not. It is just that the Concert of Europe was created mainly by autocratic monarchies, but the Treaty of Versailles was 
signed by the leaders of Western democracies. The latter were much more dependent on public sentiments in their own countries than their predecessors a century before. The public, which had gone through four years of suffering, unheard-of hardships and losses, demanded the most severe and uncompromising "punishment for the Germans." And this is exactly what the victors did, thus setting in motion preparations for a new massacre of global scale (CSR, 2018). Needless to say, the dependence of politicians on the slightest fluctuations in public sentiments has increased immensely over the past hundred years. This makes any repetition of magnanimity displayed by Alexander I or the farsightedness demonstrated by Klemens von Metternich quite unlikely today. Paraphrasing the classic, we can say that "political populism and multipolarity are two things incompatible."

There are many other examples of the modern international system which have no analogues or parallels in the Concert of Europe, such as the growing role of non-state organizations, nuclear weapons, global problems, etc. All of them make any appeal to "classical" multipolarity as the best model for the future world order unconvincing.

\section{THE COMPLEXITY OF POLE CONSOLIDATION}

What is a "pole" or a "center of power" in a multipolar world as seen by Russian advocates of multipolarity? Not every state in the world or even a coalition of states can claim to be a separate "pole" in the international system. Some authors believe that no state can be a "pole" but only a "self-sufficient civilization": "A pole in a multipolar world is a civilization + a large space (that is, cultural unity linked to a certain territorial attribute). A pole is culture + power. A pole is identity (cultural originality) + sovereignty (ability to protect originality) (Dugin, 2018).

But after all, a civilization engages in world politics mainly through the activity of states and much rarer through supranational structures (European Union or to some extent ASEAN). Civilizational identity, as Russian researcher Ivan Timofeyev (2014, p. 17) has rightfully pointed out, is subject to manipulation and crafting carried out by the state. Or these are forces that want to destroy a concrete state and build a 
new one in its place. This simple thesis makes the civilizational theory partly redundant for international relations. This is why it is assumed a priori that in most cases the "core" of a standard civilizational pole is a great power (the U.S., Russia, China, India, Brazil), around which small and medium-sized countries group in some form.

The advocates of multipolarity insist that the overwhelming majority of existing nation-states are simply not able to ensure even their own security and economic growth, let alone make any meaningful contribution to the creation of a new world order (Dugin, 2013). So, both in the current transitional world and in the future multipolar one, only a handful of countries will have "real sovereignty," while all the others sacrifice their sovereignty one way or another for the sake of security, well-being or just survival.

President Vladimir Putin made this very clear (2017) in his speech at the St. Petersburg International Economic Forum on June 2, 2017: "To reiterate, there are not so many countries that have sovereignty. Russia treasures its sovereignty, but not as a toy. We need sovereignty to protect our interests and to ensure our own development. India has sovereignty... However, there are not so many countries like India in the world. That is true. We should simply bear this in mind. India is one such country and so is China. I will not enumerate them all. There are other countries, too, but not many." So, if "mature" multipolarity is built, the number of active (full-fledged) players in world politics will be reduced by an order of magnitude, which makes relations between them much simpler and more streamlined and, therefore, makes the global system more manageable in the interests of all actors.

But while in traditional systems great powers in most cases could more or less successfully control their dependent small and mediumsized countries (even though there were many exceptions), and the number of the latter was relatively small, the situation has changed dramatically in the 21 st century. There are about 200 states in the world, which are members of the United Nations. Besides, there are unrecognized states and non-state actors engaged in world politics. So, it seems that most participants in international relations will be doomed to an unenviable role of extras or observers in a new 
multipolar world. Decisions to be made by major players will directly affect the fundamental interests of all the others.

Even if moral and ethical flaws of such a world order are put aside, there are serious doubts as to whether this project can be implemented at all, especially amid mounting problems in the existing militarypolitical and economic associations and the rapid rise of nationalism which affects not only great powers but also small and medium-sized countries.

The advocates of a multipolar world apparently think that the "poles" of a new world order will emerge naturally, and small and medium-sized countries will be joining "centers of power" not by coercion but due to geographical closeness, economic expediency, common history, cultural similarities, etc. In advancing integration processes in the former Soviet space, the Russian leadership appeals first of all to the logic of economic expediency. In his article published by Izvestia (2011), Vladimir Putin wrote: "We suggest a powerful supranational association capable of becoming one of the poles in the modern world and serving as an efficient bridge between Europe and the dynamic Asia-Pacific region... Natural resources, capital, and potent reserves of human resources will be combined to put the Eurasian Union in a strong competitive position in the industry and technology race, in the struggle for investors, for the creation of new jobs and the establishment of cutting-edge facilities. Alongside other key players and regional structures, such as the European Union, the United States, China, and APEC, the Eurasian Union will help ensure global sustainable development... Thus, our integration project is moving to a qualitatively new level, opening up broad prospects for economic development and creating additional competitive advantages. This consolidation of efforts will help us establish ourselves within the global economy and trade system and play a real role in decision-making, setting the rules and shaping the future." However, the "natural attraction" of neighboring countries rarely worked even in traditional systems. Francophonic Flanders for centuries fought off Paris' annoying patronage, Portugal tried to distance itself from geographically close Spain for just as long, Poland habitually revolted 
against being part of the Slavic unity within the Russian Empire, and Vietnam throughout centuries for some reason failed to appreciate all the advantages of belonging to the Chinese "pole."

This tendency is even more pronounced today. Suffice it to mention relations between Russia and once brotherly Ukraine or dynastic squabbles between just as "brotherly" Saudi Arabia and Qatar. Historical and cultural closeness between India and Pakistan is obvious, but so is mutual mistrust and even hostility between them. Many South Asian states, which were expected to integrate into the Indian "center of power" naturally and painlessly, prefer to develop relations with China both in the economic and security spheres. Forces of "natural attraction" remain inactive in Africa and Latin America. Britain's ongoing painful exit from the European Union is yet another proof that even a long membership in a democratic integration association provides no guarantees against destructive deep-running centrifugal forces which can outweigh considerations of economic expediency and the commonness of basic values and political practices.

Unlike its predecessors, the modern system of world politics does not recognize, at least officially, "natural spheres of influence" or "zones of special responsibility" of great powers, which makes consolidation of "poles" extremely difficult. The system can, in principle, reverse itself to legitimize "imperial" principles of organizing international relations, but we can see no signs of that happening in the foreseeable future.

As relatively weak international actors have to seek protection from great powers, in most cases they prefer to choose geographically and culturally distant partners. Such "remote" protection looks less intrusive and creates fewer risks and threats, including those for the preservation and strengthening of national identity.

Recent experience shows that even in Europe, which has gone through a decades-long integration process, the interests of national identity often outweigh economic or military-strategic interests. This explains why the present Polish leadership is demonstrating its independence from Brussels and Berlin and looking for support in Washington; and this is why the European Union is unlikely to become 
a full-fledged global center of power in the foreseeable future. If this is so, then "poles" can form only on a "voluntary-compulsory" basis, the reliability and efficiency of which look more than doubtful in the 21st century.

However, the position of leaders in the emerging "poles" looks just as dubious as that of the ones they lead. On the one hand, great powers should form around themselves a system of bilateral and multilateral unions, alliances, and coalitions in order to maximize the weight of their "pole" against other "poles." On the other hand, one of the advantages declared by great powers is their "full-fledged" national sovereignty which makes them distinct among all the other actors in world politics. In fact, preserving sovereignty is one of the main priorities for a "great-power" foreign policy.

Attempts to combine the creation of alliances with the preservation of "full-fledged" sovereignty do not look convincing. For example, Putin keeps talking about the importance for Russia of such multilateral structures as the CIS, the CSTO, EEU, SCO, and BRICS, but at the same time he says that "Russia, thank God, is not part of any alliances, and that is to a certain extent a guarantee of our sovereignty. Any country that participates in alliances cedes part of its sovereignty right away. And this does not always reflect its national interests..." (Putin, 2014a).

Let us draw some interim conclusions. Multipolar systems, as we know them, are hierarchical by nature. Therefore, new multipolarity should also envisage a certain hierarchy between the "core" and the "periphery" of individual poles, not only physical but also legalthe "core" which bears special responsibility for preserving and strengthening the center, must also have special rights necessary for effectively performing this function.

The Russian discourse on the forthcoming multipolarity suggests preserving and formalizing this hierarchy. Intentionally or not, but it mixes up the notions of legal equality and actual equality (ultimate equality). States cannot be equal to each other in practice, as their resources, possibilities, size, and potential (economic, military, political, or any other) are just too different. Yet obvious actual inequality of 
states does not necessarily mean that they should radically differ in terms of basic rights. After all, there is the principle of equality before the law which applies to all citizens regardless of the difference in their social or property status, education or talent. By denying citizens their rights, the authorities provoke revolts and revolutions; likewise, by denying small and medium-sized countries their rights, the architects of a new world order are breeding potential spoilers and revisionists.

\section{BACK TO THE BIPOLAR WORLD}

The current world situation is too different from the state of affairs that existed at the beginning of the 19th century for anyone to try to restore "classical" multipolarity. And it looks like the adherents of multipolarity today are more or less aware of this.

If one reads the modern Russian narratives describing the new multipolarity of the 21st century attentively enough, it will turn out that the lavish multipolar façade conceals a ferroconcrete bipolar structure of world politics that reflects the not yet eradicated Soviet mentality.

In the Soviet Union it was postulated that the essence of any historical epoch is determined by the main (basic, core, central) contradiction inherent in this epoch. The main contradiction is the source and driving force of historical development. "The main contradiction is the one that constitutes the essential in-depth duality of the given entity and determines the qualitative specifics of the object and its main development stages and causes the determining effect on all other contradictions. There can be only one main contradiction, and it exists from the moment of the object's emergence until its transformation into another quality (Krasin et al, eds., 1980, p. 43).

It was maintained that the main contradiction to a certain extent affects all spheres of social life, including the economy, politics, culture, morality, and international relations, of course. Needless to say, the contradiction is an antagonistic one. In other words, it cannot be resolved on the basis of some compromise, mutual concessions and reconciliation of the parties. Tactical compromises are always possible, of course, but in the final count in the main contradiction of the epoch 
the parties interact in accordance with "zero-sum game" rules. The eventual victory or loss of either party to the contradiction is a matter of time. The resolution of the main contradiction also signifies the social system's rise to a new, higher level of development, or, in Marxist terms, transition to a new socioeconomic formation.

As is known, Soviet social thought saw the main contradiction of the 20th century in the confrontation between capitalism and socialism as different and antagonist sociopolitical systems. The global standoff between the two systems was interpreted accordingly as a concrete historical manifestation of a more general contradiction between labor and capital; in other words, between the domination of capital in the bourgeois society and the power of labor in the socialist society (Semenov, 2000).

Without delving into the subtleties of Marxist-Leninist theology it is worth acknowledging that the term of the "epoch's main contradiction" provided a very convenient methodological framework for the analysis of diverse and multi-vectored phenomena of public life. A chaotic pileup of unrelated tendencies, processes and individual events was rearranged into a neat and logically complete picture of historical progress good enough not only for studies by advanced academic experts, but for everyday use and the needs of stump orators and propagandists. And not just in the Soviet Union, but also in the countries of its main adversary, the West, which eagerly accepted the proposed opposition of communism to democracy.

Possibly this is precisely what can explain why the term 'main contradiction' has survived the collapse of the world socialist system, the breakup of the Soviet Union and the universal discrediting of Marxism as "the sole correct social theory" Modern international relations are ever more often looked at in Russia through the lens of bipolarity inherited from the Soviet era.

The re-emergence of bipolar ideas proceeded alongside a worsening of Russia's relations with the West and in fact heralded departure from the basic postulates of multipolarity, although "multipolar" rhetoric retained a certain role. The general picture of the world began to be drawn increasingly in black-and-white colors. This tendency 
continued even after the Donald Trump administration took over in Washington to call in question the very existence of the united West and the existence of consolidated "ruling quarters" in the United States. Bipolar views of the world order are re-emerging simultaneously with the "militarization" of foreign policy thinking both in Russia and the West (see Kortunov, 2018b).

Just as in the case of Soviet-era bipolarity, the black-and-white picture of the world has become quite popular not only in Moscow but also in Western capitals. However, an analysis of typical Western bipolar narratives is beyond the scope of this work.

Let us take a quick look at the main modern narratives that their adepts present as postulates of the "main contradiction" in the international system of the 21 st century. It must be stated at the outset, though, that the narratives summarized below are "intersecting sets" and that they overlap, admit of various interpretations and, as a rule, have no methodological or empirical basis to rely on.

\section{OPTIONS OF NEW BIPOLARITY}

Democracy and authoritarianism. The classical neoliberal narrative, particularly in the style of the 1990s still has its followers in Russia today. It is based on the assumption that the modern world politics is a global standoff between democratic and anti-democratic (authoritarian and totalitarian) forces. In the long run democracy is destined to emerge the winner, just like the old Soviet narrative argued that communism was destined to overpower capitalism. The victory of democracy is inevitable, because the Western type of democracy remains the symbol of progress and modernity, while authoritarianism is equivalent to archaism and traditionalism. The triumph of democracy spells the end of history (Francis Fukuyama).

Currently its supporters are watching with alarm an all-out counteroffensive by anti-democratic forces and the departure of many countries from the previously chosen democratic models of development. Russia is one of the brightest examples of democracy's tactical loss. But the very narrative of confrontation between democracy and authoritarianism is not subject to revision, and Russia's eventual 
return to the democratic model of development and re-entry into the Greater West are in doubt. Such ideas are contained in the program presented by the Yabloko party in the 2016 State Duma elections. Yabloko unequivocally describes Russia as part of the Western civilization and calls for the recreation of the G8 (Yabloko, 2016).

Order and chaos. This narrative has been popular in Russia and a large part of the non-Western world. In a sense it is a response to the democracy-authoritarianism contrast. The watershed in world politics, the economy and social affairs lies between forces seeking greater controllability, stability and order in public affairs and the forces directly or indirectly breeding instability, disintegration and chaos. In other words, the world is a scene of struggle between the forces of negentropy and entropy. Clear manifestations of this struggle in international relations are seen in the current standoff in the Middle East and the West's attempts to trigger "color revolutions" in the postSoviet space. Support for chaos is paradoxically linked to attempts to preserve the old unipolar world order. This is how Sergei Lavrov (2017) has put it: "If we look at the facts, the chaos sown in Iraq and Libya, in the Middle East and North Africa in general, and the impetus given to negative processes there by external interference carried out by sheer force are the result of the unipolarity our Western colleagues are trying to preserve." Russia, naturally, is on the side of order, which is obliged to achieve an ultimate victory, because otherwise humanity will be doomed to degradation and eventual self-annihilation. An analogy of this narrative is found in the world of physics-Rudolf Clausius' theory of the heat death of the Universe, which extrapolates the second law of thermodynamics to the entire Universe. Clausius maintains that the accumulation of elements of chaos will eventually bring the Universe into a condition of thermodynamic balance or "heat death."

Conservatism and liberalism. The main condition of the epoch is seen through the lens of confrontation between the traditional conservative values (family, religion, spirituality, and communion) and neoliberal 
values (individualism, secularism, consumption, multi-culturalism, and networks instead of communities). The policy of mystical group identity is contrasted to the policy of pragmatic, group and institutional interests. This contradiction is reflected in the standoff between countries and inside individual countries (the upsurge of right-wing populism in Western Europe, Donald Trump's victory in the presidential election in the United States, the "conservative revolution" in Poland, etc. are examples). Russia's affiliation with the "conservative camp" is beyond doubt. Moreover, Russia claims to be one of the leaders of the global conservative restoration. The world is drifting towards conservatism, while neoliberalism is to suffer a historical defeat, at least in the foreseeable future.

Russian President Vladimir Putin formulated this approach in a very articulate way in his statement at the plenary meeting of the World Russian People's Council on November 1, 2018, timed for the organization's 25th anniversary: "We see the efforts that are being exerted today in an attempt to 'reformat' the world, to ruin the traditional values and cultural and historical spaces that had taken centuries to establish. The purpose is to create various 'protectorates' lacking an identity of their own. Fragmented peoples deprived of national memory and downgraded to the position of vassals are far easier and more convenient to govern and use as pawns in one's own selfish interests" (Putin, 2018). It is noteworthy that the Russian leader interprets the erosion of traditional values and national and cultural identity not as objective processes afoot in today's post-modern world, but as a result of implementing the international liberal establishment's intentional political strategy.

Nationalism and globalization. This is a variant of the previous narrative with greater emphasis on the international dimensions of social development. On one side of the border line splitting the modern world there are the advocates of unlimited globalization, the erosion of the nation-states' sovereignty and growing influence of transnational economic and financial institutions; on the other, the supporters of the Westphalian order and nationalists opposed to the 
"world conspiracy" of cosmopolitan elites. Johann Droysen's excellent work can be considered a bright illustration of the historical durability of confrontation between universalism and particularism (1995).

One of the clearest manifestations of this contradiction is seen in the acute political struggle over global migrations, protectionism, the freedom of trade, "cultural globalism," and the "national culture code." Here also belong the issues of international control of cyberspace and the future of international organizations (from the United Nations and European Union to the OSCE and OPCW). Naturally, modern Russia appears as a citadel of struggle against globalization. National sovereignty is proclaimed as one of the fundamental values.

It is important to note that in Russia's narratives globalization appears not as an objective socioeconomic trend of the modern world but as a well-targeted strategy of Western elites (primarily those connected with transnational financial groups) which pursue their own group interests.

North and South. The new split between the North and the South is the strongest contradiction of the epoch, which has replaced the split of the 20th century world along East-West lines: "At one pole of the world system there is a group of advanced democratic countries, the center of economic, technological and military might, while at the other, several dozen less developed countries of Africa and Asia, including the so-called 'failed states,' unable to maintain elementary order and quite often experiencing permanent civil war... Between these two poles there lies a diverse, mobile and constantly changing group of states going through different stages of socioeconomic development" (Torkunov, 2005).

Sometimes this bipolarity is interpreted as a standoff between the "golden billion" and the rest of humanity. The North seeks to preserve the current system of the world economy and international relations as the most beneficial one, its privileged position in the international organizations, in the information and cultural space, and in the military sphere. For its part the South demands global redistribution of resources and influence (Mahbubani, 2018). The new bipolarity is 
particularly manifest in Eurasia. As V. Kulagin states (2001, p. 12), "we are witnessing the acknowledgement of radical changes in the global geostrategic situation and a dramatic shift in the main vector of threats and challenges to global security from the 'West-East' axis left over after the Cold War, to a new dimension which can be tentatively defined as 'South-North', while the epicenter of tension is moving from the Euro-Atlantic region to the southern periphery of the Eurasian continent." In fact, the North acts in the capacity of the global bourgeoise of the 21st century, while the South is becoming the global proletariat, while the migration of millions from the South to the North is the modern equivalent of social revolutions of the past centuries. The victory of the South in the standoff with the North is more than guaranteed. It remains to be seen when the latter will surrender and on what conditions.

Russia's place in this system of coordinates is not obviouspolitical preferences push the country southwards (towards BRICS and the SCO), while many social, demographic, cultural and historical features determine its affiliation with the North.

Viktor Kremenyuk formulated an interesting point of view on the dynamics of this standoff $(2009$, p.13): "The process of reforming economic and political relations in such large countries as Russia, India, and China is capable of shifting the poor to the wealthy ratio in favor of the more developed countries. This can fundamentally change the course of human history..."

The United States and the rest of the world. This is one of the versions of the previous narrative brought to logical completion. The role of the "collective North" (or the "collective West) in the historical standoff is played solely by the United States. Back in 2000 Russian researcher Nikita Zagladin wrote: "Russian diplomacy is keen to convert the idea of multipolarity into a tool of consolidating the countries that are unhappy about the way the United States and its allies administer world leadership."

The world's development is determined by the standoff between Washington, which is out to retain its global domination in line with 
the "unipolar world concept," and all other actors of world politics, which are reluctant to accept such domination and press for the idea of a "polycentric world" as an alternative to the U.S. concept. Therefore, just like Russia, even the United States' traditional allies in Europe and Asia are objectively confronted in this dispute by the United States. The "unipolar world" is gradually fading away into the past, but relapses of the "unipolar moment" are possible and even inevitable. Russia by virtue of historical circumstances has found itself at the forefront of the struggle against U.S. ambitions, but the actual issue of the day is a global-level confrontation.

This vision of the world was spread particularly widely after the of the U.S. invasion of Iraq in 2003, when part of the U.S. allies in Europe, including France and Germany, firmly opposed the intervention. At a certain point it seemed that the emergence of a new political axisMoscow-Berlin-Paris-was a possibility. Alas, situational cooperation was not destined to evolve into strategic partnership and with the passage of time the Russian leadership in its rhetoric referred to European countries as foreign policy actors in their own right ever more rarely. Quote noteworthy was the pejorative vocabulary the Russian leader used in his February 20, 2019 Address to the Federal Assembly in relation to the United States' European allies, who "are oinking along" with the Americans (Putin, 2019).

Capitalism and socialism. This narrative postulates that the main contradiction of the 20th century - the one between labor and capitalis still there, because it was not resolved in principle with the collapse of the world socialist system. Consequently, this contradiction is being replicated and will continue to be replicated in new shapes (periodic leftward turns in Latin America, the demand for a "socially-oriented state" in Russia and the phenomena of Bernie Sanders in the United States, Jeremy Corbin in Britain, and Jean-Luc Melenchon in France). The supporters of this narrative claim that the real challenge to liberal capitalism comes not from the right (from the conservative nationalists) but from the left (from the egalitarian internationalists). A future world order will incorporate certain elements of a planned economy, social 
egalitarianism, restrictions on individual consumption, "controlled democracy" and other attributes characteristic of the Soviet Union of last century and modern China.

The program of the Russian Communist Party (CPRF) says: “The restoration of capitalism in the USSR and a number of other countries means a temporary retreat of socialism. The loss was suffered not by socialism as such, but by its early form. The forces of socialism are maturing and growing. Socialist China is developing fast. Other countries are moving along the track of building socialism. In a number of countries power belongs to the Communists or progressive parties whose leaders have a friendly attitude to this way of development. Latin American countries are following in Cuba's footsteps to demonstrate an ever firmer striving for the socialist choice. National liberation struggle is gaining strength in many countries around the world to deny to capitalism the most important reserve and source of prolonging its existence. The movement of opponents of imperialist globalization has manifested itself loudly and clearly. For this reason, there are grounds to believe that in the 21 st century socialism as a teaching, as a mass movement and as a socialist system will gain a second wind" (CPRF, n.d.).

\section{INCOMPATIBILITY OF BIPOLARITY AND POLYCENTRISM}

Again, it should be noted that none of the above-mentioned "main contradictions" can be placed anywhere near the Soviet original from the standpoint of consistency, logical cohesiveness and comprehensiveness-they are eclectic, superficial and half-baked. But in historical terms the period of time that has elapsed since the Soviet Union's breakup is relatively short for new ideologies to ripen. The current landscape of emerging bipolar narratives looks like a vast and chaotic construction site, crammed with numerous semi-finished structures of different architectural styles and made of materials of different quality and having different life cycles.

The world's return to the bipolarity of the second half of the 20th century should not be ruled out. In any case, in the context of the forthcoming U.S.-Chinese standoff such an option looks more real 
than the comeback of the "classical" 19th century multipolarity (one of the likely scenarios for the development of the current U.S.-Chinese standoff into a global bipolar system is described in: Mosyakov, 2018). Some other types of bipolarity from those listed above are possible in principle, although with varying degrees of probability. As for attempts to couple multipolarity and bipolarity within one structure, in our viewpoint they will be hopeless methodologically. The gap between the two conceptual approaches to world politics is too wide. Multipolarity and bipolarity are two fundamentally different outlooks. This explains why the architects of various "hybrid" concepts encounter significant methodological problems.

In a world of "classical" multipolarity there can be no room for strict division into right and wrong, friends and foes or black and white. As a rule, a multipolar system does not rely on values as the basis for concluding tactical coalitions and making foreign policy decisions. If circumstances change, foes within this system may turn into friends, right and wrong may swap places and a large variety of shades of grey will be discovered between the black and white ends of the scale.

On the contrary, the bipolar system is gravitating towards a conflict of values, ideological incompatibility and outspoken Manichaeism (from the Athens-Sparta standoff to the Soviet-U.S. confrontation). In a bipolar world "friends" are always right, while "foes" are invariably wrong. "Friends" are always forgiven for everything, while "foes" are never pardoned for anything. Reconciliation with the other side is impossible unless the latter fundamentally changes its nature. The idea of the "collective West," frequently used in Russia these days, is a clear sign that the old Soviet-era mentality is back. Naturally, there is no way of blending it into the declared multipolar picture of the world, but it comes in handy for creating its antagonist-the "collective non-West."

Hence the inevitable discrepancies and even contradictions in the descriptions of certain processes in different regions of the world. For instance, take Russia's vision of European integration processes. It goes without saying that only a strong and united European Union is capable of making a tangible contribution to forming a genuinely multipolar world. A weak and fragmented Europe, unable to agree 
with itself on anything serious, will always remain a sitting duck exposed to pressures, manipulations and Washington's outspoken blackmail. It is the European Union's weakness that prevents Brussels from effectively resisting the Trump administration's new sanctions against Iran or unanimously condemning the White House's decision to move the U.S. Embassy in Israel from Tel-Aviv to Jerusalem. Only a weak European Union is faced with the need to join de facto the United States' unilateral sanctions against Russia. A strong and successfully developing European Union, alongside everything else, is also a reliable and promising market for Russian goods, services and investment. This goes to show that from the standpoint of Russia's geopolitical interests Britain's pullout from the European Union should by no means be regarded as a gift of fortune.

It might seem that Russian narratives should be brimming with favorable comments regarding European integration. Such assessments were indeed quite popular at the turn of the century. Moreover, Russian leaders often said that Russia and Europe were two parts of one global pole. For example, in his speech in the Bundestag on September 25, 2010, Vladimir Putin said: "As for European integration, we not just support these processes, but we are looking at them with hope... I am just of the opinion that Europe will reinforce its reputation of a strong and truly independent center of world politics soundly and for a long time if it succeeds in bringing together its own potential and that of Russia, including its human, territorial and natural resources and its economic, cultural and defense potential" (Putin, 2001).

This and similar remarks could be interpreted as the position of "early Putin" filled with idealism about possible cooperation between Russia and Europe. But in the middle of the crisis in Ukraine, on April 17, 2014, the Russian leader said the following: "We all are people of the same civilization. Yes, we are different, we have our distinctions, but our core values are the same. I think we should without a doubt try... to create a Europe from Lisbon to Vladivostok. If we succeed, we will have a chance to occupy a worthy place in the future world. If we choose another road, if we divide Europe, European values and European peoples, and engage in separatism in a broad meaning of 
this word, we will all be insignificant players of little interest to anyone and will not be able to exert any influence on global development or even our own one" (Putin, 2014b).

But although Russia has consistently been viewing itself as part of Europe, in the current Russian discourse we quite often come across unconcealed esteem for the Eurosceptics, both right-and left-wing populists, and separatist movements in Europe. Official mass media describe in detail-quite often with a great deal of exaggerationEuropean problems related with migration, violations of financial discipline in the euro area, socioeconomic inequality, etc. (see Kortunov, 2018c). Moscow's practical steps also raise doubts that the strengthening of the European Union-regardless of "pro-European" rhetoric-is among Russia's foreign policy priorities. Suffice it to recall the more than warm welcome extended by the Kremlin to Marine Le Pen, one of the Eurosceptic leaders and head of the National Rally party, shortly before the presidential election in France in 2017 (more on Russian narratives on Europe see in Kortunov, 2018c).

Whereas one (positive) picture of modern Europe reflects the multipolar paradigm fading into the past, the other (negative) stems from the bipolar paradigm that is re-emerging before our eyes.

Overcoming the rudiments of bipolar logic is a necessary but insufficient condition for a successful foreign policy and authentic description of modern international processes. Apparently, even a more systematic and correct use of multipolar approaches does not allow for grasping the changing realities of 21 st century world politics.

Provided the equality of states in the international system is accepted as an axiom, we will have to inevitably give up some fundamental ideas of the multipolarity concept, or at least to complement them with other methodological principles. After all, this concept, just as the concept of bipolarity, overtly or covertly implies that in the world of the future there will remain individual states or their groups (poles or centers of power) enjoying special rights. In other words, the privileges of power will be established the same way the World War II victors asserted their privileges when they created the United Nations in 1945. Attempts to repeat the 1945 scenario in 2019 will be doomed 
to failure: most analysts have to acknowledge that the great powers today lack the authority, legitimacy and unanimity that was shared by the countries that made the decisive contribution to the victory in the bloodiest war in the history of the human race.

It may be surmised that major intellectual breakthroughs in developing Russia's theory of international relations can be achieved if the emphasis is shifted from the concept of multipolarity to the concept of multilaterality. While not claiming to have made a systemic and comprehensive analysis of the latter, I nevertheless would like to briefly describe its basic principles and possible directions of its further development.

\section{MULTIPOLARITY AND MULTILATERALITY}

To be stable and lasting a future international system should allow for no fundamental distinctions between the winners and losers or between "ordinary" participants and "privileged" ones. Otherwise any change in the balance of power in the world (and such changes will follow at a growing speed) will require the system to be adjusted, while persevering through ever more crises or probably even armed clashes.

Besides, it will be very hard to discuss "codification" of the privilege of power in a new multipolar environment at a time when the modern theory of international relations almost unanimously acknowledges the fact that this power is undergoing rapid diffusion. In the Congress of Vienna era power was hierarchical and easily calculable in quantitative terms and the range of its parameters was strictly limited. These days the traditional strict hierarchies of power are quickly losing their original importance. Not because the oldtime components of national power no longer work, but because new numerous components are mushrooming next to them. And assigning clear quantitative parameters to these new components in many cases turns out to be an exceptionally tricky task.

As the term 'power of states' becomes less unambiguous and acquires ever more dimensions very difficult to quantify, we inevitably encounter a no easy problem of finding a new definition for the "balance of power" in world politics. Determining a multipolar balance of 
power is not such an easy task from the methodological point of view, even when the number of parameters of power used is strictly limited and the parameters themselves are easy to gauge in quantitative terms. For instance, what is a "stable multipolar nuclear balance?" Or what is "multipolar nuclear deterrence?" (For the problems that emerge as one tries to determine the parameters of a multilateral nuclear world see: Arbatov and Dvorkin, eds., 2017.)

When the range of power parameters tends to infinity and their quantitative parameters are incalculable, the task of building a stable multipolar balance becomes unachievable. Trying to balance an open system consisting of a constantly growing number of independent variables is akin to turning a living cell into a dead crystal.

Russian scholars Vyacheslav Inozemtsev and Sergei Karaganov in 2005 remarked quite fairly that the concept of multipolarity had the same fundamental restrictions as its twin concepts of unipolarity and bipolarity: "The opponents of U.S. hegemony press for the creation of an alternative model and a multipolar world. But this viewpoint is unrealistic and old-fashioned, because the modern world cannot be arranged as a combination of counterbalancing centers of power. Just as the concept of restoring a counterbalance to the United States, this idea is not aimed at addressing new global issues. Even the meaning of the term 'multipolarity' implies rivalry in international affairs and not the striving for cooperation" (Inozemtsev and Karaganov, 2005).

A stable system of world politics implies that it should not be quite fair in relation towards the strong players, whose interests are to be restricted in the interests of the weaker ones and the interests of the system's stability in general. In any federative state resources are redistributed from well-off regions in favor of depressed onesthe thriving regions have to pay more for the sake of preserving the integrity and stability of the federation. Accordingly, at the theoretical level it is necessary to look for not so much ways of multiplying the rights of the "strong" as for the principles and mechanisms of creating extra guarantees for the "weak." This is particularly important because the "weak" have many more opportunities in the 21 st century to act 
as "spoilers" now that their chances have increased no less than by an order of magnitude from previous eras.

The elements of a future world order-as long as the focus is on order, and it is not "a game without rules" or a "war of all against all"should be built not so much on the basis of multipolarity as on the basis of multilaterality. These two terms sound alike and sometimes are used as synonyms, but their meaning is fundamentally different. It is noteworthy that in some cases certain properties attributed to the term 'multipolarity' in the Russian official discourse were pertinent rather to multilaterality. "Call it multipolarity or something elsethe name does not matter," Russian Foreign Minister Sergei Lavrov wrote (2009). "We are not in the habit of splitting hairs. The most important thing is if it really works. This is the sole yardstick of truth. In any case the point at issue is a network method of doing business in international affairs, which is an alternative to all sorts of hierarchical structures that dominated world politics just recently."

In the modern world there exist both elements of multipolarity and multilaterality. While the former take us back to the archaic forms of the world order, the latter promise a rise to a new level of global governance (Lebedeva, 2015). In the meantime, the phenomenon of multilaterality does not enjoy the attention it deserves in Russia and elsewhere. Comprehensive fundamental research into different dimensions of the emerging system of multilaterality constitutes an extremely crucial task in the theory of international relations. A synthesis of opposing approaches towards understanding global political processes has already been addressed by the author (Kortunov, 2015) in the context of possible dialogue between the advocates of geopolitics and the supporters of globalism.

While multipolarity singles out different categories of power as the basis for building a new world order, multilaterality relies on different categories of national and group interests.

While multipolarity absolutizes the term 'sovereignty' of different centers of power, multipolarity envisages mutual restriction of the sovereign rights of states for the sake of preserving the stability of the entire system. 
While a multipolar world is built of blocs counterbalancing each other, a multilateral world is built on the basis of international regimes that complement each other.

While multipolarity is in search of ways to assert the systemic privileges of frontrunners, multilaterality is focused on identifying new opportunities for those lagging behind.

While a multipolar world's development stages entail periodic adjustments of the balance of power that materialize as international crises or wars, the emergence of a multilateral world proceeds as a multistage process of accumulating elements of interdependence and of propelling the world system to new levels of integration.

In contrast to a multipolar model of a future world, the multilateral model has no significant parallels in the past, and in this sense it may seem idealistic and unachievable. One can say that if the modern world is not moving towards multipolarity, it is definitely not moving towards multilaterality either (as borne out by the Trump administration's policy).

However, certain elements of multilateral models have already been road-tested in international relations at the regional level and might serve as the basis for building new global-level theories. For instance, the principles of multilaterality, preferences for the interests of small and medium-sized countries, priority of the common normal legal basis in relation to the situational interests of individual members of the system were used to lay the groundwork for the European Union (convincing analysis of the advantages of multilaterality over multipolarity in the European Union can be found in: Krumm, 2018). Although the European Union at the moment is not in its best shape and individual components of this complex mechanism function with obvious disruptions, hardly anyone will dare deny that the EU still remains the most successful integration project that has materialized in the modern world so far.

Those who dislike the model of European integration should feel free to look for fresh sprouts of new multilaterality elsewhere. For instance, the project BRICS+ or the Community of Common Destiny concept. The architects of both initiatives are keen to avoid 
the excessive complexity, exclusiveness and strictness of the European project to offer potential partakers far more diverse cooperation options (Lisovolik, 2017). ASEAN has an interesting experience of creating a system based on multilaterality. Although these processes are far from completion, their implementation, should they succeed, will by no means bring the world closer to "classical" multipolarity. On the contrary, it will lead us farther away from multipolarity.

The international community will have to mend the legal and regulatory basis of world politics, which was seriously undermined in recent decades, to look for ways of establishing complex balances of interests at the national, regional and global levels and to create flexible mechanisms to control individual aspects of international relations. Strong countries will have to agree to considerable concessions to make multilateral agreements attractive to weaker actors. It will be necessary to discard the obsolete rudiments of mentality, inherited from the past centuries, doubtful historical analogies and attractive but meaningless geopolitical constructs.

This transition is likely to be quite painful and complex, primarily for those states which take their special status and their special rights in the international system as a given which is not to be revised or even discussed. But history shows that attempts to preserve the status quo or freeze the international system based on a totally different set of principles can never do any good, above all to those who try to do so.

The world of the future will be more complex and volatile than it looked just 20-30 years ago. There will be enough room for a variety of combinations by different world policy actors cooperating with each other in different formats. All this will require a radical upgrade and revision of the existing methodology of studying world politics both in the West and in Russia. The concept of multilaterality might become one of the guidelines to follow in this process (but it does not replace a more important and fundamental task of looking for a common "political project" that could reunite mankind again, at least by the middle of the current century). As for the concept of multipolarity, it should remain in history as a sensible intellectual and political response to inflated ambitions, arrogance and various excesses demonstrated by 
unsuccessful architects of the unipolar world, no less than that but no more either.

Today multipolarity is popular not because it has been intensively studied methodologically well enough or because it possesses a major prognostic potential. It is popular, above all, because there is a great political demand for this concept that might serve as an antagonist of the unipolar world concept (still relevant for many). But as the unipolar world concept is approaching its imminent decline, its antipode-the multipolar world concept-will inevitably face a downfall too.

\section{References}

Arbatov, A., and Dvorkin, V., eds., 2017. Politsentrichny yaderny mir: vyzovy $i$ novye vozmozhnosti [A polycentric nuclear world: challenges and new opportunities]. Moscow: Politicheskaya entsiklopediya.

Batyuk, V.I., 2010. Postbipolyarnaya retrospektiva mirovogo poryadka [A post-bipolar retrospective of the world order]. Mezhdunarodnye protsessy [International Trends], 8(2). Available at: <http://intertrends.ru/old/twentythree/009.htm> [Accessed 10 January 2019].

Bogaturov, A.D., 1996. Plyuralisticheskaya mnogopolyarnost' i interesy Rossii [Pluralistic multi-polarity and Russia's interests]. Svobodnaya mysl', 2, pp. 25-36.

Concept, 2016. Kontseptsiya vneshnei politiki Rossī̄skoī Federatsii [The Foreign Policy Concept of the Russian Federation] [online]. Available at: <http:// kremlin.ru/acts/bank/41451> [Accessed 10 January 2019].

CPRF, n.d. Programma Partii [Program of Communist Party of Russian Federation]. Available at: <https://kprf.ru/party/program $>$ [Accessed 04 February 2019].

CSR, 2018. Woodrow Wilson's fourteen points 100 years on: rethinking the liberal world order. Center for Strategic Research, January, Moscow [pdf]. Available at: <https://www.csr.ru/wp-content/uploads/2018/01/ReportWilson-Web-EN-1.pdf> [Accessed 12 January 2019].

Declaration, 1997. Rossī̄sko-kitaīskaya sovmenstnaya deklaratsiya o mnogopolyarnom mire $i$ formirovanii novogo mezhdunarodnogo poryadka [Russian-Chinese Joint Declaration on a Multipolar World and the Formation of a New International Order] [online]. Available at: <http://docs.cntd.ru/ document/1902155> [Accessed 08 January 2019]. 
Droysen, J. G., 1995. Istoriya ellinizma [History of Hellenism], 3 volumes. Translated from German. Rostov-on-Don: Feniks.

Dugin, A.G., 2013. Teoria mnogopolyarnogo mira [Theory of a multipolar world]. Moscow: Yevraziīskoe dvizhenie, pp. 16-19.

Dugin, A.G., 2018. Kitaiskaya Mechta: ot robkoi gegemonii k mnogopolyarnomu miru [Chinese Dream: from tentative hegemony to a multipolar world]. Geopolitica.ru, 31 December, [online]. Available at: $\quad<$ https://www.geopolitica.ru/article/kitayskaya-mechta-ot-robkoygegemonii-k-mnogopolyarnomu-miru> [Accessed 16 January 2019].

Fenenko, A., 2018. Chto nuzhno dlya mnogopolyarnosti [What is needed for multi-polarity?]. Russian International Affairs Council (RIAC), 6 July [online]. Available at: <http://russiancouncil.ru/analytics-and-comments/analytics/ chto-nuzhno-dlya-mnogopolyarnosti/> [Accessed 12 January 2019].

Inozemtsev, V. and Karaganov, S., 2005. O mirovom poryadke XXI veka [On the world Ooder in 21st century]. Rossiya $v$ global'noi politike [Russia in Global Affairs], 3(1) [online]. Available at: <https://globalaffairs.ru/number/n_4476> [Accessed 23 February 2019].

Kortunov, A., 2015. The Splendours and Miseries of Geopolitics. RIAC, 14 January [online]. Available at: <http://russiancouncil.ru/en/analytics-andcomments/analytics/the-splendours-and-miseries-of-geopolitics/> [Accessed 02 March, 2019].

Kortunov, A., 2016. The inevitable, weird world. RIAC, 20 July [online]. Available at: <http://russiancouncil.ru/en/analytics-and-comments/analytics/ neizbezhnost-strannogo-mira/> [Accessed 01 March 2019].

Kortunov, A., 2018a. Why the world is not becoming multipolar. RIAC, 27 June [online]. Available at: <http://russiancouncil.ru/en/analytics-and-comments/ analytics/why-the-world-is-not-becoming-multipolar/> [Accessed 01 March 2019].

Kortunov, A., 2018b. Politics as continuation of war by other means? RIAC, 26 October [online]. Available at: <http://russiancouncil.ru/en/analyticsand-comments/analytics/politics-as-continuation-of-war-by-other-means/> [Accessed 01 March 2019].

Kortunov, A., 2018c. What kind of Europe does Russia need? RIAC, 05 September [online]. Available at: $<\mathrm{http} / / /$ russiancouncil.ru/en/analytics-andcomments/analytics/what-kind-of-europe-does-russia-need/> [Accessed 02 March 2019]. 
Kozyrev, A.V., 1994. Strategiya partnerstva [Partnership strategy]. Mezhdunarodnaya zhisn' [International Affairs], 5.

Krasin, Yu. A., et al., eds., 1980. Dialektika razvitiya sotsialisticheskogo obshchestva [Dialectics of socialist society development]. Moscow: Mysl'.

Kremenyuk, V.A., 2009. Poryadok posle krizisa: kakim emu byt'? [Post-crisis order: What should it be like?]. Mezhdunarodnye protsessy [International Trends], 8(2).

Krumm, Reinhard, 2018. Multipolar or multilateral? A choice of models for the security order 2.0: Congress of Vienna, Yalta, Helsinki. Vienna: FES Regional Office for Cooperation and Peace in Europe, March [online]. Available at: $<$ https://www.fes-vienna.org/publications/?tx_digbib_digbibpublicationlist $\% 5$ BpageIndex\%5D=2> [Accessed 23 January 2019].

Kulagin, V.M., 2001. Rossiya - SShA. Koe-chto nachinaet poluchat'sya [Russia - the USA. Something Begins to Work Out]. Mezhdunarodnaya zhisn' [International Affairs], (12)

Lavrov, S., 2007. The Present and the future of global politics. Russia in Global Affairs, 5(2) [online]. Available at: <https://eng.globalaffairs.ru/ number/n_8554> [Accessed 20 January 2019].

Lavrov, S., 2009. Potentsial peremen [Potential for change]. Rossiiskaya gazeta, 08 September [online]. Available at: <https://rg.ru/2009/09/08/lavrov.html> [Accessed 29 January 2019].

Lavrov, S., 2014. Interview with the All-Russia State Television and Radio Broadcasting Company regarding the birthday of Yevgeny Primakov, 28 October. MFA Press service. Transcript [online]. Available at: <http://www.mid.ru/ en/press_service/minister_speeches/-/asset_publisher/7OvQR5KJWVmR/ content/id/781648> [Accessed 08 January 2019].

Lavrov, S., 2017. Mnogie politiki yavlayutsya storonnikami teorii upravlyaemogo haosa [Many politicians advocate the theory of controlled chaos]. TASS, 11 August [online]. Available at: <https://tass.ru/ politika/4477015> [Accessed 10 January 2019].

Lavrov, S., 2019. Stanovlenie politsentrichnogo mira zaīmet desyatiletiya [The polycentric world will take decades to develop]. Nezavisimaya gazeta, 25 February [online]. <http://www.ng.ru/news/640835.html> [Accessed 27 February 2019].

Lebedeva, O.V., 2015. Mnogostoronnyaya diplomatiya v sovremennyh mezhdunarodnyh otnosheniyah [Multilateral diplomacy in the modern 
international relations]. Pravo $i$ upravlenie XXI vek [Journal of Law and Administration], 34(1), pp. 86-90.

Lisovolik, Ya., 2017. BRICS-Plus: alternative globalization in the making? Valdai Discussion Club. Valdai Papers \#69, July [online]. Available at: <http:// valdaiclub.com/files/14927/> [Accessed 23 January 2019].

Littlejohn, S.W., 1994. Theories of human communication. Belmont, Calif.: Wudthworth Publishing Company.

Mahbubani, K., 2018. Has the West lost it? A Provocation. London: Allen Lane. Mosyakov, D., 2018. My vnov' idem k bor'be dvuh system? [Are we bound towards the two systems' clash again?]. Russian International Affairs Council (RIAC), 30 October [online]. Available at: $<\mathrm{http}: / /$ russiancouncil.ru/analyticsand-comments/analytics/my-vnov-idem-k-borbe-dvukh-sistem/> [Accessed 29 January,2019].

Nikonov, V., 2002. Back to the Concert. Russia in Global Affairs 1(1) [online]. Available at: $<$ https://eng.globalaffairs.ru/number/n_12> [Accessed 10 January 2019].

Primakov, Ye., 1996. Mezhdunarodnye otnosheniya nakanune XXI veka: problemy, perspekyivy [International relations on the eve of the 21st century: problems and prospects]. Mezhdunarodnaya zhisn' [International Affairs], 10, pp. 3-13.

Primakov, Ye., 2001. Mysli vsluh [Thoughts Out Loud]. Moscow: Rossīiskaya Gazeta.

Primakov, Ye., 2009. Mir bez Rossii? K chemu vedet politicheskaya blizorukost' [A world without Russia? What may political short-sightedness lead to?]. Moscow: Rossiīskaya Gazeta.

Putin, V., 2001. Vystuplenie v Bundestage FRG [Address at Bundestag, FRG], 25 September. Transcript [online]. Available at: http://www.kremlin.ru/events/ president/transcripts/21340 [Accessed 02 March 2019].

Putin, V., 2006. Vystuplenie na sovestchanii s poslami $i$ postoyannymi predstavitelyami Rossīskoi Federatsii [Address at the meeting with Ambassadors and Permanent Representatives of the Russian Federation], 27 June. Transcript [online]. Available at: http://www.kremlin.ru/events/ president/transcripts/23669 [Accessed 15 January 2019].

Putin, V., 2011. Novyī integratsionnyī proekt dlya Yevrazii-budushchee, kotoroe rozhdaetsya segodnya [A New integration project for Eurasia-the future born today]. Izvestia, 03 October [online]. Available at: <https://iz.ru/ news/502761> [Accessed 16 January 2019]. 
Putin, V., 2014a. Vystuplenie na zasedanii Soveta Bezopasnosti [Address at the meeting of the Security Council of the Russian Federation], 22 July. Transcript [online]. Available at: <http://kremlin.ru/events/president/news/46305> [Accessed 17 January 2019].

Putin, V., 2014b. Pryamaya liniya s Vladimirom Putinym [Putin Live on TV], 17 April. Transcript [online]. Available at: $<$ http://kremlin.ru/events/president/ news/20796> [Accessed 02 March 2019].

Putin, V., 2016a. Vystuplenie na plenarnom zasedanii Peterburgskogo mezhdunarodnogo ekonomicheskogo foruma [Address at the Plenary Session of the 2016 St. Petersburg International Economic Forum], 17 June. Transcript [online]. Available at: <http://www.kremlin.ru/events/president/news/52178> [Accessed 10 January 2019].

Putin, V., 2016b. Vystuplenie na zasedanii Mezhdunarodnogo discussionnogo kluba "Valdǟ" [Address at the Valdai Discussion Club meeting], 27 October. Transcript [online]. Available at: <http://www.kremlin.ru/events/president/ news/53151> [Accessed 10 January 2019].

Putin, V., 2017. Vystuplenie na plenarnom zasedanii Peterburgskogo mezhdunarodnogo ekonomicheskogo foruma [Address at Plenary Session of the 2017 St. Petersburg International Economic Forum], 02 June. Transcript [online]. Available at: <http://www.kremlin.ru/events/president/news/54667> [Accessed 16 January 2019].

Putin, V., 2018. Vystuplenie na zasedanii Vsemirnogo russkogo narodnogo sobora [Address at the meeting of the World Russian People's Council], 01 November. Transcript [online]. Available at: <http://www.kremlin.ru/events/president/ news/59013> [Accessed 19 January 2019].

Putin, V., 2019. Poslanie Prezidenta Federal'nomu Sobraniyu [Presidential Address to the Federal Assembly], 20 February. Transcript [online]. Available at: <http://kremlin.ru/events/president/news/59863> [Accessed 24 February 2019].

Rice, Condoleezza, 2003. Polyus svobody i spravedlivosti [The pole of freedom and justice]. Rossiya v global'noi politike [Russia in Global Affairs], 2(3) [online]. Available at: <https://globalaffairs.ru/number/n_1564> [Accessed 08 January 2019].

Rogov, S.M., 1992. Rossiya i SShA v mnogopolyarnom mire [Russia and the United States in a multipolar world]. SShaA: ekonomika, politika, ideologia [USA: economics, politics, ideology], (10). 
Semenov, V.S., 2000. Uroki XX veka i put'v XXI vek. Social'no-filosofskii analiz i prognoz [Lessons from the 20th century and the way to the 21st century. Sociophilosophical analysis and forecast]. Moscow: IF RAN.

Shakleina, T., (aquis.), Torkunov. A., et al. (eds.), 2002. Vneshnyaya politika i bezopasnost' sovremennoī Rossii. Khrestomatiya $\mathrm{v}$ chetyreh tomah [Foreign policy and national security of modern Russia. A four-volume anthology]. Vol. IV. Moscow: ROSSPEN.

Sutyrin, V., 2016. Gde iskat' al'ternativu liberal'nomu mirovomu poryadku? [Where tolook for an alternative to the liberal world order]? In: Mezhdunarodnye otnosheniya: ratsional'nyī mirovoī poradok? [International relations: a rational world order?] RIAC, Working papers. No. 34, Moscow.

Timofeev, Ivan, 2014. Mirovoi poryadok ili mirovaya anarhiya? [World order or word anarchy?] RIAC, Working papers, No. 1, Moscow.

Timofeev Ivan, 2019. Political multipolarity vs. economic unipolarity: 2018 results and 2019 intrigues. Valdai Discussion Club. Expert Opinions, 05 January [online]. Available at: $<$ http://valdaiclub.com/a/highlights/politicalmultipolarity-vs/> [Accessed 20 January 2019].

Torkunov, A.V., 1999. Mezhdunarodnye otnosheniya posle kosovskogo krizisa [International relations after the Kosovo crisis]. Mezhdunarodnaya zhisn' [International Affairs] (12), pp. 45-52.

Torkunov, A.V., 2005. Ot "holodnoī voīny" k "koalitsii pobedy" [From the Cold War to the "Victory Alliance"]. Kosmopolis (4), Winter 2004-2005.

Yabloko, 2016. Predvybornaya programma partii "Yabloko": "Uvazhenie $k$ cheloveku" [Yabloko party electoral program: "Respect for Man]. Available at: $<$ https://www.yabloko.ru/program\#_Toc459908182> [Accessed 19 January 2019].

Zagladin, N.V., 2000. "Novyī mirovoī besporyadok" i vneshnyaya politika Rossii ["New world disorder" and Russia's foreign policy]. Mirovaya ekonomika i mezhdunarodnye otnosheniya [World Economy and International Relations], 1.

Zhao Suisheng, 2004. Beijing's perceptions of the international system and foreign policy adjustment after the Tiananmen incident. In: Suisheng Zhao (ed.) Chinese Foreign Policy. Pragmatism and Strategic Behavior. New York: East Gate Book. 